\title{
Creating An Enabling Environment For A Successful Partnership In Housing Delivery. (A Case Study of Kaduna State, Nigeria).
}

\author{
D. M. Abeku \\ Department of Building, \\ Federal University of Technology, Minna, Niger State. \\ C. K. Luka \\ Department of Building, \\ Ahmadu Bello University, Zaria.
}

\begin{abstract}
The provision of affordable housing in Nigeria has remained a mirage in spite of the huge deficit which is put at seventeen (17) million units required to bridge the gap, unfortunately, government's effort in terms of policy, funding, direct construction and mortgage provisions has yielded next to nothing over the years as the gap keeps widening. It is as a result of this that government introduced the public private partnership (PPP) arrangement to cater for infrastructural deficit, housing inclusive. The methodology include the inductive method where stakeholder organizations such as Kaduna Investment Promotion Agency (KADIPA), Kaduna Geographic Information Systems (KADGIS), Kaduna Urban Planning and Development Authority (KASUPDA), Kaduna Roads Agency (KADRA), Kaduna Power Supply Company (KAPSCO), Kaduna State Water Corporation (KADSWAC), Kaduna State Development and Property Company Limited (KSDPC) and Ministry of Works, Housing and Transport (MOWH\&T) were visited to ascertain their involvement in the housing effort of the state. The researchers also visited five (5) housing development sites to confirm the information from the side of the government. Results showed that seventeen (17) developers have been engaged by the state government through the ppp arrangement within the last two (2) years with an approximate size of 185.8 hectares of land shared among the developers at various locations within the metropolis who are developing various types of houses. The challenge of affordability of the houses to the poor and low income earners still remains a major problem as the average price of one bedroom semi detach is between $\mathrm{N} 3$ million and N4 Million, while a two bedroom semi detach is put at N6 million and a three bedroom ranges between N7.5 million and $\mathrm{N} 8$ million. To the poor, these prices are extremely high and unattainable. Therefore, house ownership for this category remains a tall dream. The study recommends the construction of the single room (studio) apartments and the sourcing of cheaper building materials to construct these houses so that the poor and the low income earners can afford them.
\end{abstract}

\section{INTRODUCTION}

The Nigerian housing deficit is put at 17 million units and there is no commensurate effort being made either by government or the private sector or both, towards the reduction of this deficit.

The 1999 Nigerian constitution compels the Nigerian state in section sixteen (16) sub section one (1) under the fundamental objectives of state policy that the state should provide adequate shelter for all citizens.

The United Nations human rights declaration (1948) declares in article 25(1) that everyone has the right to a standard of living adequate for the health and well being of himself and of his family, including food, clothing, housing and medical care and necessary social services... 
Housing is one of the basic needs of mankind, after food and clothing, unfortunately in Nigeria, its provision has not been able to match the demand due to rapid population growth which we were not prepared for (Omolabi and Adebayo, 2017).

Beside the population growth, there is also the major problem of urban migration from the rural areas. Most citizens migrate to the cities in search for white collar jobs, better opportunities and the need for an improved social life. As a result; the houses in the cities are inadequate in supply and where they are available, too expensive for the poor and low-income earners to acquire (Abeku et.al.,2016).

The World Bank observes that Nigeria needs to produce about 720,000 units of houses annually for the next 20 years to solve the problem.

This is indicative of the enormity of the housing challenge in Nigeria.

Again, the Nigerian 2020 development strategy which includes a vision to build 10,398,650 housing units between 2012 and 2020 corroborates the assertion of the World Bank (Housing Finance in Africa Yearbook, 2012, pp III)

Government has not been able to maintain a steady provision of the houses for citizens and there has also been the problem of changes in governments, different kinds of policies and policy changes on the housing matter leading to no progress at all.

Diogu (2002) and Ukoha and Beamish (1996) posited in their different works that in spite of optimistic housing policies by government since the 1960s, results have remained largely unimpressive as housing provision has remained far short of policy projections.

It has since been observed that government alone cannot meet the growing demand for affordable houses in Nigeria. In view of this, there is therefore the need for partnership with the private sector, donor agencies and others in order to improve on the current situation.

Pursuant to this, government introduced the Public-Private Partnership (PPP) arrangement to cater for or reduce the existing huge gap on infrastructure development, housing inclusive.

According to the Federal Government's National Policy on Public - Private Partnership (PPP), global demand for basic infrastructure services has grown over the years, quickly outstripping the supply capacity of existing assets. Many years of under investment and poor maintenance have left Nigeria with a significant infrastructure deficit which is holding back the country's development and economic growth. Nigeria needs to make massive investments beyond the means available to government in order to close its yawning infrastructure gap. It is the government's belief that the private sector can play an important role in providing some of the new investments through Public - Private Partnership (PPP) arrangement.

The scope of the government's PPP include: the creation of new infrastructure and the expansion and refurbishing of existing assets such as:

1. Power generation plants and transmission/distribution networks

2. Roads and bridges

3. Ports

4. Airports

5. Railways

6. Inland container depots and logistics hubs 
7. Gas and petroleum infrastructure such as storage depots and distribution pipelines

8. Water supply, treatment and distribution systems

9. Solid waste management

10. Educational facilities (school, universities, colleges, etc)

11. Urban transport systems

12. Housing

13. Healthcare facilities.

The government went further to create the infrastructure concession regulatory commission (ICRC) with a clear mandate to develop and issue guidelines on PPP policies, processes and procedures and to act as a national centre of expertise in PPP.

Another major challenge is the provision of mortgages to Nigerian citizens to enable them own houses.

Sonnie Ayere the chairman of Mortgage ware house Funding limited said in Punch Online News Paper of $22^{\text {nd }}$ January 2018 that the problem of high interest rates charged by mortgage institutions is one of the major reasons why Nigerians do not patronize mortgage institutions. Ayere added that the interest rate ranges between 22 to $25 \%$ which is very high for any meaningful patronage. He posited that many people prefer to buy cash rather than utilize the mortgage arrangement and that even when the tenure is between 20 to 25 years, people chose to pay up quickly so as to cut interest.

Ayere added that with this kind of high interest rate, the poor and the low-income earners have no hope of enrolling. Considering what is expected of them as regards the quantum of money to be repaid. Ayere on the other hand posited that the problem is being looked into by the Nigerian Mortgage refinancing company which is to assist the mortgage banks with long-term financing with over 20 years tenor. This we hope will bring down the interest on mortgages.

This study aims at examining the level of success achieved as a result of the effort made by Kaduna State in partnering with private developers for housing provision in the state.

\section{METHOD}

The methodology adopted for this study include the inductive qualitative method were interviews were conducted with stake holders such as KADIPA, KADGIS, KASUPDA, KADRA, KAPSCO, KADSWAC, KSDPC and MOWH\&T as regards Kaduna State's involvement. Also photographs of some of the sites visited were taken and presented in this study.

The key areas/blocks in the Housing Partnership between the state and the developers include:

1. Land acquisition/provision

2. Tittle documentation, cost and duration of same

3. Vetting and approval of designs as presented by Developers

4. Handing over of sites to developers, ensuring elimination of encumbrances or compensation problems.

5. Provision of infrastructure such as roads, water and electricity.

6. Supervision of developers works to ensure minimum quality standards are maintained

7. Others

8. 


\section{RESULTS AND DISCUSSION}

Below is a summary of the transcript of results of the interviews conducted with the stakeholders' organization

\section{Kaduna Investment Promotion Agency (KADIPA):}

The Executive Director (Investment) was interviewed on the modalities of engaging private developers or partners. The ED gave the basic areas of consideration as:

- The reason for the developer's choice of Kaduna State/Town as destination for investment was asked. The researcher discovered that over $90 \%$ of those engaged said they chose Kaduna due to its proximity to the Federal Capital Territory Abuja. Also $50 \%$ of them also gave the reason of return on investment as part of the reasons for choosing Kaduna, while $30 \%$ of them posited that the high cost of Land in Abuja informed the reason for their choice of Kaduna as an alternative destination.

The ED added that KADIPA usually request the developers to send in their proposals which are usually vetted earlier, then, they are invited for oral discussion (interview). In some instances, KADIPA sometimes visit the developers' offices to verify some of the claims presented in the proposals.

- The next most important criteria as given by KADIPA is the developer's financial stand. Checks are made on the developer's financial stand. Checks are made on the bank balances. Partnership with financial institutions is also considered important.

This, the ED posited that it very important because there are developers' who collect sites and end up abandoning same due to lack of funds.

- The aspect of Technical man power and availability of equipment for the jobs is also given a look in.

- KADIPA also discusses the responsibilities and details of the benefits accruable to both parties, that is the state government and the developer.

- The ED gave the following details of developers engaged by Kaduna State through the PPP arrangement. 19 developers in all and distributed to different layouts provided for them which are broadly divided into two as Millennium city layout and other locations. This is given is tables 1 and 2 below. Note that the names of the companies will not be given in this work so as to protect the officer who provided the information. The companies are designated using alphabets instead. 
Table 1: Kaduna State PPP Housing Scheme at Millennium City Layout.

\begin{tabular}{|c|c|c|c|c|c|c|}
\hline S/No & Developer & Land Size & Project Name & $\begin{array}{l}\text { Types of } \\
\text { Houses }\end{array}$ & Current Status & Remarks \\
\hline 1 & A & 15 hectares & $\begin{array}{l}\text { Mass housing } \\
\text { dev. }\end{array}$ & $\begin{array}{l}1 \& 2 \mathrm{Bed} \\
\text { room mix } \\
\text { houses }\end{array}$ & $\begin{array}{l}\text { Developer just } \\
\text { commenced work }\end{array}$ & \\
\hline 2 & B & 15 Hectares & $\begin{array}{l}250 \mathrm{nr} .2 \text { bed } \\
\text { room } \\
\text { apartments }\end{array}$ & $\begin{array}{l}2 \text { bed room } \\
\text { houses }\end{array}$ & $\begin{array}{l}\text { Work on a good } \\
\text { number of houses in } \\
\text { progress }\end{array}$ & $\begin{array}{l}\text { Infrastructure } \\
\text { and } \\
\text { compensation } \\
\text { problems. }\end{array}$ \\
\hline 3 & C & 18 Hectares & $\begin{array}{l}\text { Mass housing } \\
\text { dev. }\end{array}$ & $\begin{array}{l}1 \& 2 \text { Bed } \\
\text { rooms } \\
\text { prototype }\end{array}$ & $\begin{array}{l}2 \text { bed room section in } \\
\text { progress. }\end{array}$ & \\
\hline 4 & $\mathrm{D}$ & 10 Hectares & $\begin{array}{l}\text { Mass housing } \\
\text { dev. }\end{array}$ & $\begin{array}{l}1,2 \& 3 \text { bed } \\
\text { rooms mixed } \\
\text { housing }\end{array}$ & $\begin{array}{l}\text { Approval granted and } \\
\text { access provided, but } \\
\text { yet to start work. }\end{array}$ & \\
\hline 5 & $\mathrm{E}$ & 10 Hectares & $\begin{array}{l}\text { Special housing } \\
\text { for Legislators } \\
\text { \& Judiciary }\end{array}$ & Duplexes & At approval stage. & \\
\hline 6 & $\mathrm{~F}$ & $\begin{array}{c}6.8 \\
\text { Hectares }\end{array}$ & $\begin{array}{l}\text { Mass housing } \\
\text { dev. }\end{array}$ & $\begin{array}{l}2 \& 3 \text { bed } \\
\text { rooms }\end{array}$ & $\begin{array}{l}\text { Work just commenced } \\
\text { on site. }\end{array}$ & \\
\hline 7 & G & 5 Hectares & $\begin{array}{l}\text { Mass housing } \\
\text { dev }\end{array}$ & $\begin{array}{l}2 \& 3 \mathrm{Bed} \\
\text { rooms }\end{array}$ & $\begin{array}{l}\text { Work just commenced } \\
\text { on site. }\end{array}$ & \\
\hline 8 & $\mathrm{H}$ & 5 Hectares & $\begin{array}{l}\text { Affordable } \\
\text { housing } \\
\text { scheme }\end{array}$ & $\begin{array}{l}1,2 \& 3 \text { Bed } \\
\text { rooms mixed } \\
\text { Housing }\end{array}$ & $\begin{array}{l}\text { Work has just } \\
\text { commenced }\end{array}$ & \\
\hline 9 & I & 7 Hectares & $\begin{array}{l}\text { Affordable } \\
\text { housing } \\
\text { scheme }\end{array}$ & $\begin{array}{l}1,2 \& 3 \text { bed } \\
\text { room mixed } \\
\text { housing }\end{array}$ & $\begin{array}{l}\text { Work is progressing } \\
\text { on site. }\end{array}$ & \\
\hline
\end{tabular}

Source: Researcher's field work, 2018

Table 2: Kaduna State PPP Housing Scheme at Other Layouts

\begin{tabular}{|c|c|c|c|c|c|c|}
\hline S/No & Developer & Land Size & $\begin{array}{l}\text { Project } \\
\text { Name }\end{array}$ & Location & $\begin{array}{l}\text { Type of } \\
\text { Houses }\end{array}$ & $\begin{array}{l}\text { Current } \\
\text { Status } \\
\end{array}$ \\
\hline 1 & $\mathrm{~J}$ & $\begin{array}{c}10 \\
\text { Hectares }\end{array}$ & $\begin{array}{l}\text { Affordable } \\
\text { mass housing } \\
\text { lot } 1\end{array}$ & $\begin{array}{l}\text { Sobawa, } \\
\text { Rigachikun }\end{array}$ & $\begin{array}{l}2 \& 3 \text { Bed } \\
\text { rooms houses }\end{array}$ & $\begin{array}{l}\text { Developer } \\
\text { just took } \\
\text { possession of } \\
\text { site }\end{array}$ \\
\hline 2 & K & 5 Hectares & $\begin{array}{l}\text { Mass housing } \\
\text { dev }\end{array}$ & Yakowa road & $\begin{array}{l}2 \& 3 \text { Bed } \\
\text { room houses }\end{array}$ & $\begin{array}{l}\text { Work is at } \\
60 \% \\
\text { completion }\end{array}$ \\
\hline 3 & $\mathrm{~L}$ & $\begin{array}{c}10 \\
\text { Hectares }\end{array}$ & $\begin{array}{l}\text { Affordable } \\
\text { housing lot } 1\end{array}$ & $\begin{array}{l}\text { Sobawa } \\
\text { Rigachikun }\end{array}$ & $\begin{array}{l}1,2 \& 3 \text { Bed } \\
\text { rooms types }\end{array}$ & $\begin{array}{l}\text { Work in } \\
\text { progress on } \\
\text { site }\end{array}$ \\
\hline 4 & M & 8 Hectares & $\begin{array}{l}\text { Affordable } \\
\text { housing lot } 3\end{array}$ & $\begin{array}{l}\text { Sobawa } \\
\text { Rigachikun }\end{array}$ & $\begin{array}{l}2 \& 3 \mathrm{Bed} \\
\text { rooms houses }\end{array}$ & $\begin{array}{l}\text { Work in } \\
\text { progress on } \\
\text { site. }\end{array}$ \\
\hline 5 & $\mathrm{~N}$ & 5 Hectares & $\begin{array}{l}\text { Affordable } \\
\text { housing types }\end{array}$ & $\begin{array}{l}\text { Ungwan } \\
\text { Tanko }\end{array}$ & $\begin{array}{l}1,2 \& 3 \text { Bed } \\
\text { rooms types }\end{array}$ & $\begin{array}{l}\text { Just obtained } \\
\text { approval }\end{array}$ \\
\hline 6 & 0 & $\begin{array}{c}10 \\
\text { Hectares }\end{array}$ & $\begin{array}{l}\text { Affordable } \\
\text { housing } \\
\text { scheme }\end{array}$ & $\begin{array}{l}\text { Buwaya } \\
\text { Eastern bye } \\
\text { pass }\end{array}$ & $\begin{array}{l}1,2 \& 3 \text { Bed } \\
\text { rooms types }\end{array}$ & $\begin{array}{l}\text { Work just } \\
\text { began on site. }\end{array}$ \\
\hline 7 & $\mathrm{P}$ & 5 Hectares & $\begin{array}{l}\text { Affordable } \\
\text { housing } \\
\text { scheme }\end{array}$ & $\begin{array}{l}\text { Ungwan } \\
\text { Tanko }\end{array}$ & $\begin{array}{l}1,2 \& 3 \text { Bed } \\
\text { rooms types }\end{array}$ & $\begin{array}{l}\text { Work just } \\
\text { began on site. }\end{array}$ \\
\hline 8 & Q & 8 Hectares & $\begin{array}{l}\text { Affordable } \\
\text { housing } \\
\text { scheme }\end{array}$ & $\begin{array}{l}\text { Buwaya } \\
\text { Eastern bye } \\
\text { pass }\end{array}$ & $\begin{array}{l}1,2 \& 3 \text { Bed } \\
\text { rooms types }\end{array}$ & $\begin{array}{l}\text { Waiting for } \\
\text { plan approval } \\
\text { by KASUPDA }\end{array}$ \\
\hline
\end{tabular}

Source: Researcher's field work 2018. 


\section{Kaduna Geographic Information System (KADGIS)}

The researchers visited KADGIS where they were ushered to the Chief Land Administration officer (CLA) for the interview.

Details were sought from the officer as to how developers obtain land and how the titles are documented.

The CLA posited that one of the cardinal points of this present administration is to woo investors into the state. As a result of this, certain areas have been designated and earmarked for the purpose of mass housing programmes. $95 \%$ of the developers that came were given the land based on the house types and number of units that the developer desires to build. From the list, it will be seen that various sizes of land have been issued to the developers. The normal practice is that KADGIS carries out the following responsibilities:

(i) The plot of land is allocated to the developer conveyed via allocation letter/title documents.

(ii) The plot of land is surveyed, beacons are capped and the TDP drawn and handed over to the developer.

(iii) The Certificate of Occupancy ( $\mathrm{C}$ of $\mathrm{O}$ ) is prepared and issued to the developer within a very short period of time - note that these certificates do not go through the normal process; they are processed using a bypass process.

(iv) KADGIS also sorts out all encumbrances on the land such as compensation issues before handing over same to the developer.

\section{Kaduna State Urban Planning And Development Authority (KASUPDA)}

KASUPDA is the planning authority of the state. The researchers on visiting KASUPDA sought to meet with the General Manager (GM and that was granted.

Detail of the procedure for obtaining planning approval by developers was sought by the researchers and the GM gave the following response:-

The GM said after the developer has been engaged by KADIPA and the matter of the plot of land on which the development will be carried out haven been finalised by KADGIS, the developer is asked to present the designs of the housing types intended to be built on the plot and the arrangement of the buildings on the site layout plan to KASUPDA for vetting, costing and approval.

The GM presented the researchers with a copy of the planning manual that the company uses and said that there are five types of permits that KASUPDA issues, namely: -

(i) Regular planning / development permit

(ii) Fast-track planning permit

(iii) Implementation permit

(iv) Final certificate of completion

(v) Decoration / improvement notice

Out of the five types of permits above, housing developers enjoy the fast-track planning permit due to the state government's order that they should be given special consideration. The fast track planning permit is handled within 14 days of payment of fees, within which it is expected that the developer will obtain the required development permission to carry on with development at the designated plot(s). According to the General Manager, nineteen (19) housing developers have been issued with development permit, while three (3) others are under review at the moment. 
INFRASTRUCTURE PROVIDING AGENCIES

There are three agencies involved in the provision of infrastructure namely: Kaduna Roads Agency (KADRA), Kaduna State Water Corporation (KADSWAC) and Kaduna Power Supply Company (KAPSCO), these agencies were visited by the researchers to ascertain their level of involvement in the housing provision effort.

\section{Kaduna Roads Agency (KADRA):}

This is the agency involved in the provision and maintenance of roads in the state. The agency was visited by the researchers to find out if the agency is involved in the provision of roads for any housing developer; the General Manager said the state government does not have the resources to develop road network for housing estates, but rather, the agency has the instruction of the state government to provide roads to the sites of the developers where such roads do not exist (access roads), as for the internal roads, that is left for the developers to handle.

\section{Kaduna Power Supply Company (KAPSCO)}

This is the agency involved with the provision of electricity.

The researchers visited the agency but the Executive Director said they do not have any mandate to provide electricity to any housing developer at the moment. This could be as result of the fact that most of the developers are still handling the construction of the houses yet.

\section{Kaduna State Water Corporation (KADSWAC)}

This agency was visited by the researchers to ascertain the agency's involvement with the developers in the provision of pipe borne water at the housing developers' sites and the Director of Administration, who was the staff the researchers visited, reported that they have government's instruction to provide water to any housing development site where there is a water line passing near the area, but where such pipelines do not exist the agency is doing a thorough assessment of the cost implication to be presented to the state government for consideration.

\section{KADUNA STATE DEVELOPMENT AND PROPERTY COMPANY LIMITED (KSDPC)}

The researchers visited the above named company to ascertain its involvement in the housing effort of the state. The Executive Director Operations (EDO) of the company was the officer interviewed by the researchers. This was his response to the enquiry made by the researchers who asked to know the effort being made by the company as regards housing development. The EDO said the state government recently granted the company autonomy to operate as a private company, where it should source for its funds and do its own business without government's intervention. In view of that, the company recently sought for partnership with the state government just like the private housing developers are doing for the purpose of acquiring land to develop its own houses for sale to the public. The EDO added that he is glad to notify the researchers that the effort has yielded result where government allocated land to the company in two different locations at Sobawa in Rigachikun and at Millennium city layout, all within Kaduna metropolis for development. Both plots of land are currently being demarcated with beacons and infrastructural development of streets is also being carried out.

\section{MINISTRY OF WORKS, HOUSING AND TRANSPORT (MWH\&T)}

The ministry's Department of Building which is responsible for the housing aspect of the ministry was visited by the researchers. The director of the department was interviewed as to what role the ministry plays on the mass housing issue. 
His response was that the department has the responsibility of supervising the developers to ensure that quality is maintained in the development of the houses so that the off takers will have value for money.

The director added that a team of four (4) technical staff from the department comprising two (2) Architects and two (2) Builders have been constituted into a technical team that visits developer's sites weekly for proper inspection to enforce quality compliance. The team submits its report to his office weekly. The director concluded that there is synergy between the ministry and KADIPA which is the agency responsible for engaging the developers. That as soon as the agency has consummated the Memorandum of Understanding (MOU) with the developer(s), they usually send the details to the ministry to take over the supervision of the activities of the developers in their various sites. He further added that, the effort of the team is yielding result, because any poor quality work noticed is usually communicated to the developer in writing and a copy kept in the department for record purpose and for checks to determine whether there is compliance. So far the result of the team's effort is encouraging.

\section{DEVELOPERS}

Five (5) developers were visited by the researchers.

The questions asked were:

(i) How did you come about the choice of Kaduna State as your destination for Housing development?

(ii) How were you able to convince the government to partner with you in terms of land allocation and other incentives?

(iii) How are you able to arrange for infrastructure for your site, roads, water and electricity?

In response to the above questions, four (4) out of the five (5) housing developers posited that their choice of Kaduna is informed by the proximity of Kaduna to Abuja the Federal Capital Territory (FCT) and also the availability/lower cost of the land compared to Abuja (FCT) informed their choice.

The other developer posited that their company is domiciled in Kaduna town and they chose to provide housing in Kaduna as their area of operation.

The response of the developers on the question concerning government's consideration of their companies for partnership, all the developers visited posited that they believe their acceptability by the government as development partners was due to three things that took place:

(i) The packaging of their company profiles indicating their experience in housing provision and their financial capacity.

(ii) The submitted resumes of the key staff and the equipment of the companies as presented to government for consideration.

(iii) The report of the technical committee that visited the offices of the developers to confirm the submission of the companies.

The developers believe that the three issues presented above must have been the reason for government's acceptance of their choice for partnership. 
On the issue of infrastructural development on the housing sites, four (4) out of the five (5) developers visited said they intend to provide only single coat surface dressed roads within their estates, while only one is providing asphalt road network within the estate.

Water is to be provided using boreholes and overhead tanks in all the sites visited, while electricity will be stepped down and transformers installed within the estates in three (3) of the five (5) sites visited. The other two (2) will have to extend the electricity from different points to their sites.

\section{Photo Album}

These are some of the houses under construction by the developers.

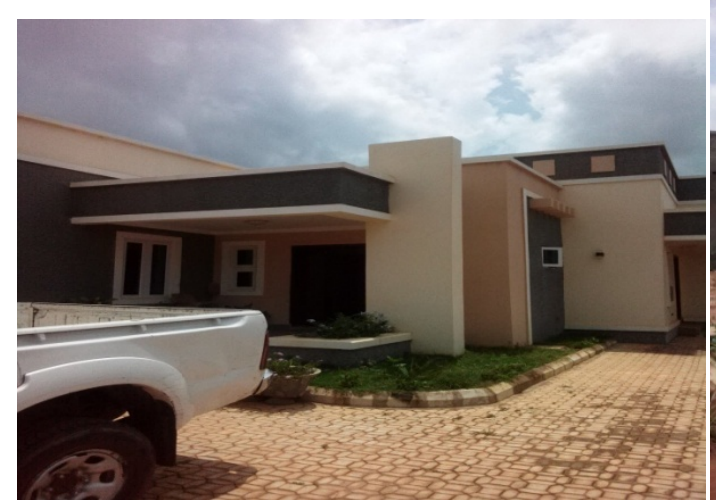

Development by developer G.

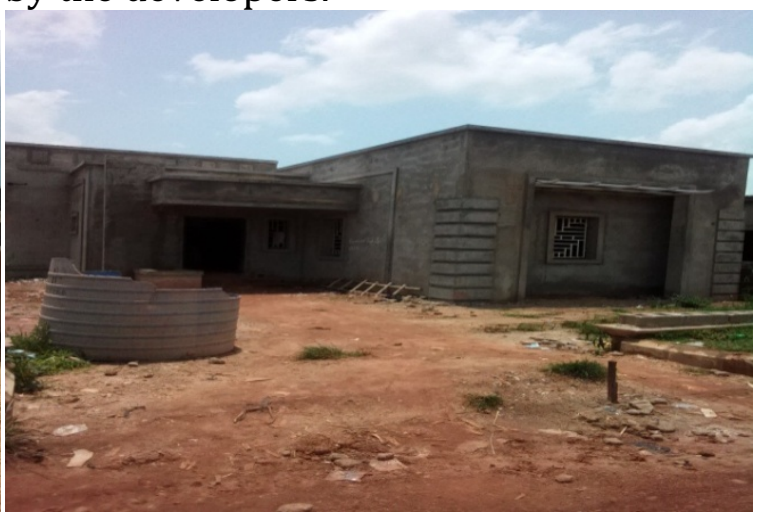

Researcher's field work, 2018.

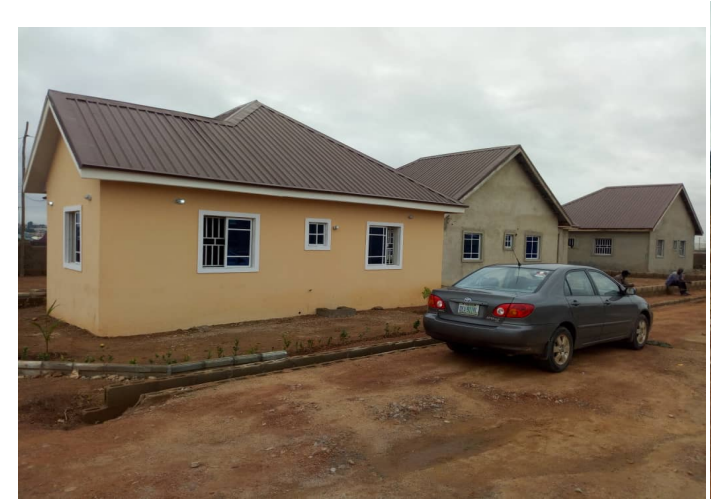

Development by developer K

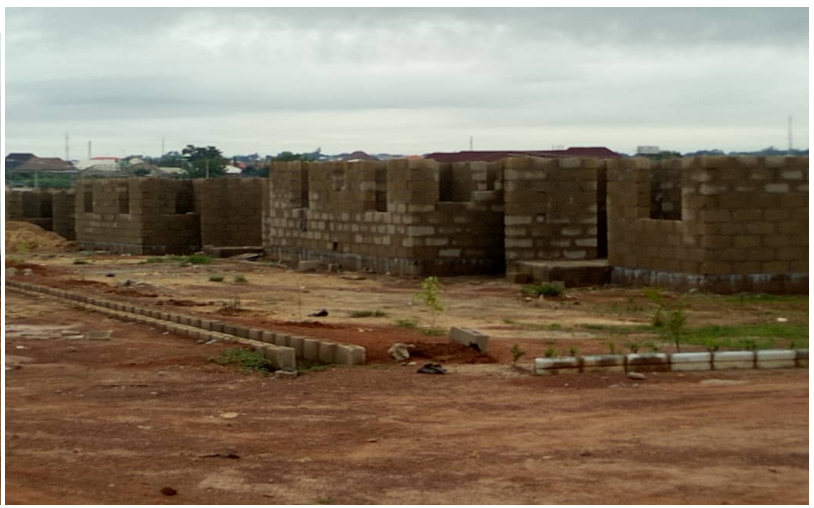

Researcher's field work 2018.

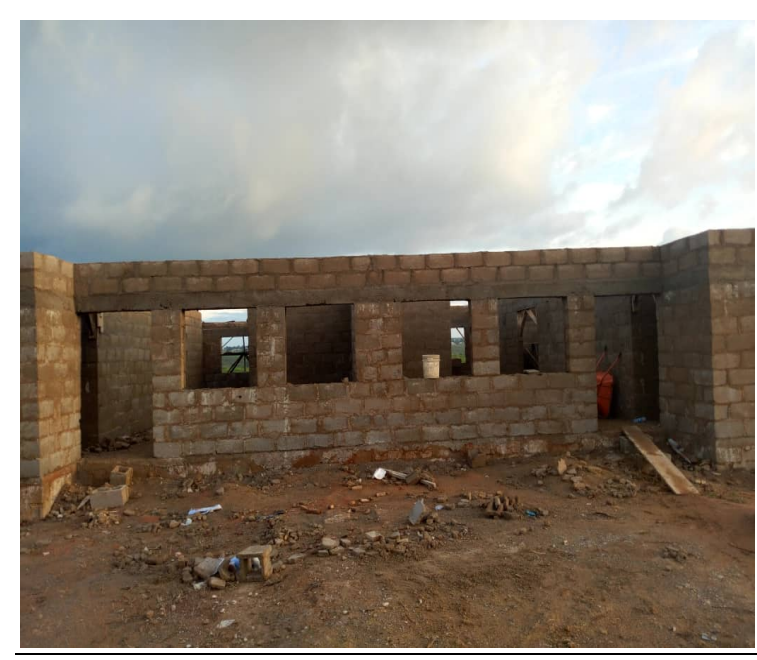

Development by developer 0

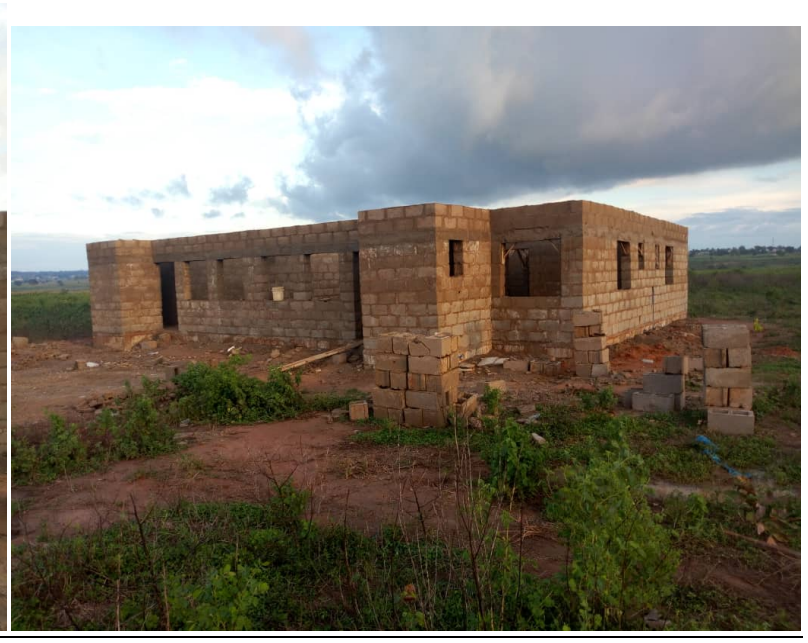

Researcher's field work 2018. 


\section{CONCLUSION}

Housing is no doubt a major necessity of life and a measure of the standard/status of a man's life in the society. The need for its provision cannot be over emphasized, more so that we have a huge deficit in our hands to deal with.

The current effort of Kaduna state in partnering with developers for its provision is highly commendable, but more effort is required by the state to woo more developers by making more land available for the housing programme and reduce/remove the bureaucracy in the title documentation of such lands.

This research concludes that the ongoing effort should be sustained even if there is a change in government so that more houses will be available to citizens in the coming months/years.

\section{RECOMMENDATIONS}

- The state government should support and ensure that all the National Housing Fund deductions made from the salaries of its employees (both state and local governments) are remitted monthly.

- Government should encourage the participation of more private estate developers to the existing ones by wooing more of them and further make more land available to them at highly subsidized rates. This will help reduce the final price of the houses when constructed as the cost of land will either be removed or reduced from the final price.

- The state government should facilitate the establishment of state owned primary mortgage institution(s) that will serve the citizens with relative ease.

- The state housing development agency(s) should be recapitalized and empowered to enable them address the housing problems in the state.

- There should be budgetary provisions in the annual budget by the state to be utilized for the development of low - income mass housing within the state annually.

- The state government should further improve on the already existing reduced bureaucracy in the processes and procedures of land tilting and documentation at the land registries.

- The state should also support and put in place a policy that will bring a drastic reduction in the statutory and other land/mortgage transactions costs.

- The states should support the preparation of a state Building Code in order to standardize construction and to minimize risk associated with poor quality buildings delivered in the state.

\section{References}

Abeku, D.M., Salifu, C. and Kure, M.A. (2016) Housing deficit, Urban migration and slum development in Abuja, Nigeria. International journal of Economic Development, Research and Investment. 7(1), pp 39 - 50

Ayere, S. (2018) Investment in Mortgage'll help reduce housing deficit. Punch online Newspapers. 22 January 2018. Accessed on the 22nd August 2018

Diogu, J.O. (2002). Housing the poor in Nigeria: The integrated Project Approach, AARCHES Journal, 2(1), pp 4044.

Draft PPP Manual for Nigeria (2017) Infrastructural Concession Regulatory Commission Nigeria. By Nigeria Infrastructure advisory facility. pp 25.

Housing Finance in Africa Yearbook, 2012, pp III

Kaduna State Urban Planning and Development Agency (KASUPDA) Manual. Development control guide, 2018; pp $9-78$ 
Omolabi, A.O and Adebayo, P.W. (2017) - "An assessment of the housing policy performance towards public lowincome housing provision and management in Lagos, Nigeria." International Journal of Development and Sustainability. 6(8), pp $792-809$.

The universal declaration of human rights (UDHR), 1948. Article 25(1). General Assembly resolution 217A, 10 th December, 1948, Paris France

The 1999 Nigerian Constitution

Ukoha, O.M. and Beamish, J.O. (1996) Predictors of Housing Satisfaction in Abuja, Nigeria. Housing and Society, 23(3), pp 26-46. 